Arch. Tierz., Dummerstorf 42 (1999) 6, 629-639

Friedrich-Wilhelm-University Bonn, Institute of Animal Sciences', Humboldt-University Berlin, Institute of Livestock Sciences², Obafemi Awolowo University lle-Ife, Nigeria, Department of Animal Science?

KLAUS WIMMERS', SIRILUCK PONSUKSILI', FRIEDRICH SCHMOLL', TORSTEN HARDGE $^{2}$, E. BABAFUNSO SONAIYA ${ }^{3}$, KARL SCHELLANDER' und PETER HORST ${ }^{2}$

\title{
Application of microsatellite analysis to group chicken according to their genetic similarity
}

Dedicated to Professor Dr. Peter Glodek on the occasion of his $65^{\text {th }}$ birthday

\begin{abstract}
Summary
When estimating genetic variability of groups of local chicken from Nigeria we had to deal with the problem that the groups could not be regarded as distinct breeds or strains. The original sample groups obviously just represent individuals sampled in the same geographical region. The aim was to arrange these chicken in new groups according to their genetic similarity. Therefore 60 chicken from Nigeria and 10 Dahlem Reds (RIR) were genotyped at 20 microsatellite loci. In order to build up new groups "allele sharing" was calculated as the proportion of shared alleles between each pair of individuals and was used to construct a dendrogram of all individuals including Dahlem Reds as a reference group which represents a well defined line. All Dahlem Reds clustered in this dendrogram indicating that this is an adequate approach to group individuals according to their common genetic make-up. The Nigerian chicken were arranged in 7 new groups. CHORD genetic distances between these new groups ranged from 0.07 to 0.27 and were higher than the values revealed by the original local sample groups $(0.05-0.16)$.
\end{abstract}

Key Words: microsatellite, chicken, genetic distance, allele sharing, heterozygosity

\section{Zusammenfassung}

Titel der Arbeit: Gruppierung von Hühnern entsprechend ihrer genetischen Ähnlichkeit basierend auf Mikrosatelliten-Analysen

Bei der Untersuchung der genetischen Variabilität von Gruppen lokaler Hühnerpopulationen aus Nigeria trat das Problem auf, daß diese Gruppen nicht eindeutig definierte Rassen oder Linien darstellten. Vielmehr handelte es sich um Gruppen von Hühnern, die in Orten der jeweils gleichen geographischen Region gesammelt wurden. Diese Tiere sollten entsprechend ihrer genetischen Ähnlichkeit neu gruppiert werden. Dazu wurden 60 Hühner aus Nigeria und 10 Tiere einer experimentellen Roten Rhodeländer Linie an 20 Mikrosatelliten genotypisiert. Zur Neugnuppierung wurde der Allel-Übereinstimmungsgrad (allele sharing) als Anteil übereinstimmender an der Gesamtzahl der Allele zwischen allen Paaren von Tieren berechnet. Anschließend wurde ein Dendrogramm aller Tiere, einschließlich der Roten Rhodeländer als Referenzgruppe, erstellt. Innerhalb des Dendrograms befanden sich alle Roten Rhodeländer in einem Kluster, was darauf hinweist, daß der Ansatz geeignet ist, Individuen entsprechend ihrer genetischen Ähnlichkeit zu gruppieren. Die Nigerianischen Hühner wurden 7 Gruppen zugeordnet. Die CHORD genetische Distanz zwischen diesen neuen Gruppen lag zwischen 0,07 und 0,27 und damit deutlich höher als zwischen den Originalgruppen $(0,05$ bis 0,16$)$.

Schlüsselwörter: Mikrosatelliten, Hühner, genetische Distanz, allele sharing, Heterozygotie

\section{Introduction}

In chicken breeding high selection pressure and the use of only a few breeds potentially leads to the loss of genetic variation. This is mostly recognised as the loss of rare breeds especially in developed countries. This led to the sense that the identifi- 
cation of important genetic resources and the prevention of further loss of genetic variation is an important task (FRANKHAM, 1994). In developing countries selection pressure for production traits is low and traditional breeds are used in rural animal production systems. Therefore the evaluation of exotic local breeds as genetic resources is of interest in efforts to maintain genetic variation.

We estimated the genetic variability within and between groups of local chicken from several tropical countries in order to identify genetic resources. It became obvious that at least some of these groups could not be regarded as distinct local populations since genetic distance between these groups was low and phenotypic variation within the groups was high. These groups were just made up of individuals sampled in the same geographical region. Here we exemplary show the assortment of chicken according to their genetic similarity based on the calculation of "allele sharing" of 20 microsatellite loci.

\section{Material and Methods}

Chicken:

Microsatellite loci were genotyped in 60 Nigerian chicken collected and evaluated in the framework of the EC-Project „Evaluation of local poultry resources for creating genetic stock with improved adaptability, productivity and disease resistance in tropical environments" (STD3-Program, project-leader: P.Horst). The chicken were sampled in different villages and towns of 5 ecological zones including savannah and rain forest areas and were originally grouped according to these ecological zones. The sample size of the 6 original local sample groups named Ife, Kaduna, Florin, Makurdi, Jos and Sagamu was between 4 and 15. These chicken showed a high variation for example in traits like bodyweight, laying performance, feather and comb colour/type not only between but even within the groups. Unfortunately, phenotypic descriptions of the individuals of the original local sample groups could not be assorted to the DNA samples used. Additionally 10 Dahlem Reds, (RIR), an experimental line derived from commercial Rhode Island Reds, were used as a reference.

\section{Genotyping:}

The animals were genotyped at 20 microsatellite loci (Table 1) using PCR reactions containing $50 \mathrm{ng}$ of genomic DNA, $1.5 \mathrm{mM} \mathrm{MgCl}_{2}, 200 \mu \mathrm{M}$ dNTPs, $0.50 \mu \mathrm{M}$ of each primer, $1 \mathrm{U}$ Tag polymerase $\left(30\right.$ cycles: $\left.1 \min 94^{\circ} \mathrm{C}, 1 \mathrm{~min} 55^{\circ} \mathrm{C}-60^{\circ} \mathrm{C}, 1 \mathrm{~min} 72^{\circ} \mathrm{C}\right)$. Fragment analyses were performed on an automated DNA Sequencer A.L.F. (Pharmacia Biotech).

Genetic variation estimates:

The software package GENEPOP V1.2 (RAYMOND et al., 1995) was used in order to calculate expected and observed heterozygosity. Heterozygosity estimates based on genotyping results at all loci were checked for deviation from Hardy-Weinberg equilibrium with the same software package. As a measure of deviation the $\mathrm{F}_{\mathrm{IS}}$-values were calculated as $\mathrm{F}_{\mathrm{IS}}=\left(\mathrm{H}_{\mathrm{c}}-\mathrm{H}_{\mathrm{o}}\right) / \mathrm{H}_{\mathrm{c}}$, where $\mathrm{H}_{c}$ is the average expected heterozygosity 
and $\mathrm{H}_{\mathrm{o}}$ is the average observed heterozygosity. The type-I error probability and level of significance of deviations from Hardy-Weinberg equilibrium of all populations summed over all loci were computed. The polymorphic information content, PIC, (BOTSTEIN et al., 1980) of the microsatellite loci analysed was calculated.

CHORD genetic distance, dij, was calculated using the PHYLIP computer package (Phylogeny Interference Package) Version 3.5p (Copyright 1986-1993 by J. FELSENSTEIN, University of Washington) (CAVALLI-SFORZA and EDWARDS, 1967). The results of these estimations were used to construct genetic trees by UPGMA cluster analyses (unweighted pair-group method using arithmetic averages), a standard algorithm for agglomerative clustering (ROHLF, 1993). The reliability of the results was evaluated by bootstrapping using the adequate option of the PHYLIP software package.

Allele sharing, AS, was calculated as the proportion of shared alleles over all loci and used as a measure of genetic similarity between individuals. A distance measure between pairs of individuals was calculated as 1-AS.

\section{Results}

The 20 microsatellites used showed between 2 and 11 alleles, their polymorphic information content, PIC, ranged between 0.11 and 0.72 (Table 1).

Table 1

Map position, the number of alleles and PIC-values obtained with 20 microsatellite markers in the chicken populations (Kartierungsort, Anzahl der Allele und PIC-Werte in den Hühnerpopulationen von 20 Mikrosatelliten)

\begin{tabular}{llcc}
\hline Microsatellite & Linkage group & \# of Alleles & PIC \\
\hline ADL20 & E1; C6 & 5 & $.46 \pm .08$ \\
ADL23 & E7, C2 & 6 & $.64 \pm .07$ \\
ADL37 & E1, C6 & 3 & $.11 \pm .11$ \\
ADL39 & E18 & 3 & $.48 \pm .14$ \\
ADL40 & E11 & 4 & $.55 \pm .11$ \\
ADL44 & E16, C18 & 6 & $.63 \pm .14$ \\
ADL158* & C30, E29 & 2 & $.36 \pm .03$ \\
ADL171* & E43 & 2 & $.18 \pm .13$ \\
ADL176* & E6 & 3 & $.36 \pm .05$ \\
ADL210* & E30 & 5 & $.47 \pm .13$ \\
ADL267* & C3, E6 & 4 & $.50 \pm .23$ \\
HUJ1 & E1 & 9 & $.70 \pm .18$ \\
HUJ2 & E8, C17 & 11 & $.31 \pm .18$ \\
HUJ6 & E2 & 4 & $.60 \pm .06$ \\
HUJ7 & E7, C2 & 10 & $.28 \pm .15$ \\
HUJ12 & E4, C12 & 8 & $.72 \pm .12$ \\
MCW1* & E3 & 3 & $.20 \pm .15$ \\
MCW4* & E2 & 5 & $.60 \pm .03$ \\
MCW7 & E1, C15 & 4 & $.33 \pm .07$ \\
MCW73* & E46 & 6 & $.57 \pm .19$ \\
\hline${ }^{\circ}$ microsatellites recommended in the FAO's MODAD-program & &
\end{tabular}

Observed heterozygosity within the original groups of Nigerian chicken was moderate with values between 0.5 and 0.6 . For the Dahlem Reds observed heterozygosity was 0.56 (Table 2). 
Table 2

Observed and expected heterozygosity and Fis-values calculated over 20 microsatellite loci of the original groups of Nigerian chicken grouped according to the place of sampling and RIR (Beobachtete und erwartete Heterozygotie und Fis-Werte berechnet über 20 Mikrosatelliten Loci der Nigerianischen Hühner in ihrer ursprünglichen Gruppierung (nach der Region der Sammlung) und der Roten Rhodeländer)

\begin{tabular}{lccc}
\hline Population & $\begin{array}{c}\text { observed } \\
\text { Heterozygosity }\end{array}$ & $\begin{array}{c}\text { expected } \\
\text { Heterozygosity }\end{array}$ & Fis \\
\hline Ife & 0.53 & 0.57 & $-0.173^{\text {**** }}$ \\
Kaduna & 0.59 & 0.53 & $0.080^{\text {*** }}$ \\
Ilorin & 0.50 & 0.54 & $-0.120^{\text {*** }}$ \\
Makurdi & 0.57 & 0.59 & $0.077^{\text {*** }}$ \\
Jos & 0.60 & 0.54 & 0.037 \\
Sagamu & 0.57 & 0.55 & $-0.111^{\text {*** }}$ \\
RIR & 0.56 & 0.48 & $-0.045^{* * *}$ \\
Mean & 0.56 & 0.54 & -0.029 \\
\hline${ }^{\circ}<0.05,{ }^{\circ 0}<<0.01,{ }^{* 0 * 0} \mathrm{P}<0.001$ & &
\end{tabular}

Heterozygosity estimates based on genotyping results at all loci were checked for deviation from Hardy-Weinberg equilibrium (Table 2). For all groups - except for Jos significant deviation was found. The results at each single locus revealed that positive as well as negative $\mathrm{F}_{\mathrm{IS}}$-values were estimated but there was no systematic deviation of one locus in all populations. There was no population which showed only positive or only negative $\mathrm{F}_{\mathrm{IS}}$-values at all loci.

Table 3

Genetic distance matrix of the original sample groups of Nigerian chicken and RIR (Genetische Distanzmatrix der Nigerianischen Hühner in ihrer ursprünglichen Gruppierung und der Roten Rhodeländer)

\begin{tabular}{lcccccc}
\hline & Ife & Kaduna & Ilorin & Makurdi & Jos & Sagamu \\
\hline Kaduna & 0.0855 & & & & & \\
Ilorin & 0.0789 & 0.0809 & & & & \\
Makurdi & 0.0541 & 0.1262 & 0.0834 & & & \\
Jos & 0.1385 & 0.1467 & 0.1216 & 0.1359 & & \\
Sagamu & 0.0778 & 0.1328 & 0.1378 & 0.1153 & 0.1573 & \\
RIR & 0.3249 & 0.3847 & 0.3787 & 0.3413 & 0.3716 & 0.3618 \\
\hline
\end{tabular}

CHORD genetic distance was calculated using the appropriate options of software package PHYLIP. The values of CHORD distance between all populations are shown in Table 3. Genetic distances between the original Nigerian groups of chicken ranged between 0.05 (Ife-Makurdi) and 0.16 (Jos-Sagamu). Genetic distance of the original Nigerian chicken groups to Dahlem Reds was between 0.32 (Ife-Dahlem Reds) and 0.38 (Kaduna-Dahlem Reds).

Dendrograms were constructed with the UPGMA method (Fig. 1).Within this tree Kaduna and Ilorin as well as Ife and Makurdi were grouped together and made up the first cluster. The other groups were assorted one after the other in the order: Sagamu, Jos, Dahlem Reds. Bootstrapping values were between 46 and $99.9 \%$.

For the following reasons the Nigerian chicken were arranged in new groups: (1) genetic distance values obtained between Nigerian populations and their genetic distance to the Dahlem Reds were substantially lower than observed with other local 
Table 4

Observed and expected heterozygosity and Fis-values calculated over 20 microsatellite loci of 7 groups of Nigerian chicken grouped according to their genetic similarity and RIR (Beobachtete und erwartete Heterozygotie und Fis-Werte berechnet über 20 Mikrosatelliten Loci der Nigerianischen Hühner in ihrer neuen Gruppierung (nach der genetischen Ähnlichkeit) und der Roten Rhodelånder)

\begin{tabular}{llll}
\hline Population & $\begin{array}{l}\text { observed } \\
\text { heterozygosity }\end{array}$ & $\begin{array}{l}\text { expected } \\
\text { heterozygosity }\end{array}$ & Fis \\
\hline NG1 & 0.56 & 0.57 & $0.026^{*}$ \\
NG2 & 0.56 & 0.54 & $-0.027^{* * *}$ \\
NG3 & 0.55 & 0.56 & 0.032 \\
NG4 & 0.54 & 0.57 & $0.054^{\text {**** }}$ \\
NG5 & 0.60 & 0.55 & -0.101 \\
NG6 & 0.57 & 0.57 & -0.004 \\
NG7 & 0.51 & 0.57 & 0.141 \\
N-RIR & 0.56 & 0.50 & $-0.119^{* * *}$ \\
Mean & 0.56 & 0.56 & -0.001 \\
\hline
\end{tabular}

${ }^{\mathrm{P}}<0.05,{ }^{* \mathrm{P}}<0.01,{ }^{* * * \mathrm{P}}<0.001$

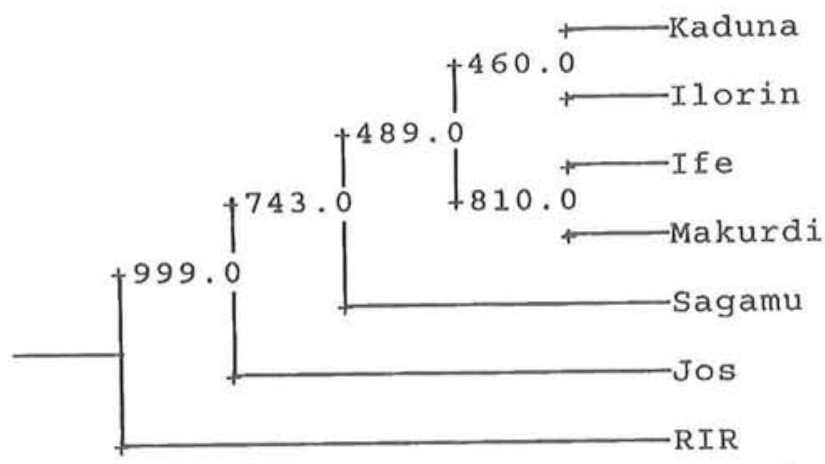

Fig. 1.: Dendrogram of the original groups of Nigerian chicken (grouped according to the place of sampling) and RIR based on UPGMA clustering of CHORD genetic distance values (Dendrogramm der Nigerianischen Hühner in ihrer ursprünglichen Gruppierung (nach der Region der Sammlung) und der Roten Rhodeländer basierend auf UPGMA-Klusteranalyse von CHORD genetischen Distanzen)

populations of tropical countries (data not shown), (2) a high variation for example in traits like bodyweight, laying performance, feather and comb colour/type within the groups the Nigerian local populations was observed, (3) the size of some of the original groups was quite low. The new groups were arranged based on the knowledge of marker genotypes and genetic distance between these new groups were calculated.

Since comparisons between individuals were necessary which could not be done based on allele frequencies "allele sharing, AS" was calculated as the proportion of shared alleles over all loci. A symmetric dissimilarity matrix was calculated with 1-AS. Using the UPGMA clustering method dendrograms were constructed including individuals of Dahlem Reds as reference group which represents a well defined line (Fig. 2).

Within the dendrogram all Dahlem Reds clustered. One individual of the original group Jos appeared within the cluster of Dahlem Reds. New groups were designed by taking into account the genetic distances between individuals of the group of Dahlem 


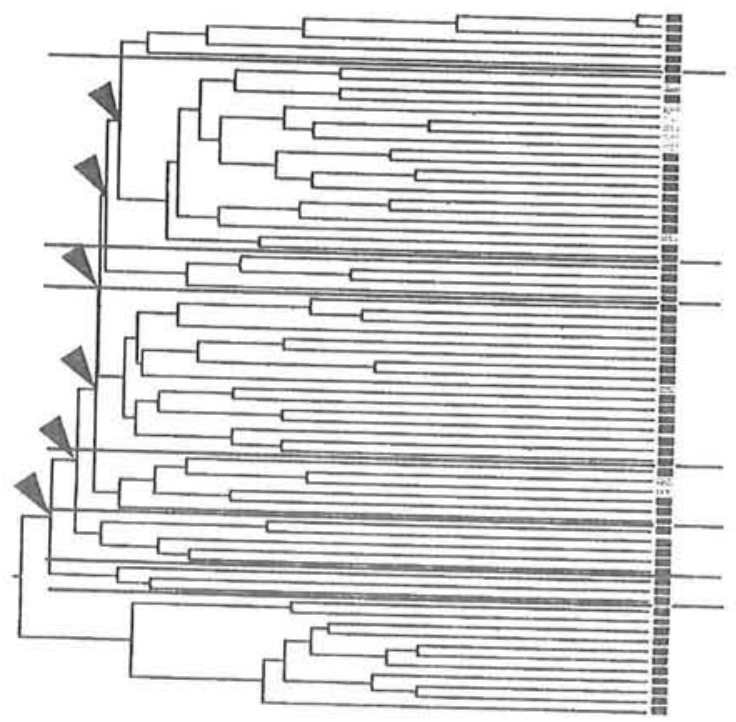

Fig. 2.: Dendrogram of 70 individuals based on UPGMA clustering of the genetic distance measure 1-AS (Dendrogramm der 70 Individuen basierend auf UPGMA-Klusteranalyse des genetischen Distanzmaßes 1-AS)

Reds as indicated by the length of the branches within the tree. By this approach 7 clusters were determined which represent the new groups. The first cluster consists of 6 out of 15 animals originally assigned as Ife. The second cluster was composed of 1 individual from the local group Ife $(n=15), 7$ from Kaduna $(n=10), 6$ from Ilorin $(n=9)$, 3 from Makurdi $(n=13)$ and 2 animals from the original group named Jos $(n=4)$. The third cluster contained 2 animals from Ife and 2 from Ilorin. The fourth cluster was mixed up of animals from the original groups Ife (1/15), Kaduna (1/10); Ilorin (1/9), Makurdi (5/13), Jos (1/4) and Sagamu (7/9). The next cluster consisted of individuals from the groups Ife (2/15), Kaduna (2/10), Makurdi (1/13) and Sagamu (1/9). Following 1 animal from Ife and 4 from Makurdi were grouped together. The seventh cluster was made of 2 animals from the group Ife and 1 from Sagamu.

Table 5

Genetic distance matrix of the Nigerian chicken and RIR arranged into new groups (Genetische Distanzmatrix der Nigerianischen Hühner in ihrer neuen Gruppierung und der Roten Rhodeländer)

\begin{tabular}{|c|c|c|c|c|c|c|c|}
\hline & NG1 & NG2 & NG3 & NG4 & NG5 & NG6 & NG7 \\
\hline $\begin{array}{l}\text { NG3 } \\
\text { NG4 }\end{array}$ & 0.2091 & $\begin{array}{l}0.1616 \\
0.0724\end{array}$ & 0.1276 & & & & \\
\hline $\begin{array}{l}\text { NG4 } \\
\text { NG5 }\end{array}$ & $\begin{array}{l}0.0912 \\
0.1801\end{array}$ & $\begin{array}{l}0.0724 \\
0.1242\end{array}$ & 0.2025 & 0.0938 & & & \\
\hline $\begin{array}{l}\text { NG5 } \\
\text { NG6 }\end{array}$ & $\begin{array}{l}0.1801 \\
0.2066\end{array}$ & $\begin{array}{l}0.1242 \\
0.1673\end{array}$ & 0.1587 & 0.1360 & 0.1660 & & \\
\hline $\begin{array}{l}\text { NG6 } \\
\text { NG7 }\end{array}$ & $\begin{array}{l}0.2066 \\
0.2292\end{array}$ & $\begin{array}{l}0.1673 \\
0.1938\end{array}$ & 0.1915 & 0.1774 & 0.2183 & 0.2681 & \\
\hline $\begin{array}{l}\text { NG7 } \\
\text { N-RIR }\end{array}$ & $\begin{array}{l}0.2292 \\
0.2757\end{array}$ & $\begin{array}{l}0.1938 \\
0.2215\end{array}$ & 0.2859 & 0.2024 & 0.2860 & 0.3389 & 0.3391 \\
\hline
\end{tabular}

Subsequently genetic variation within and between these new groups were estimated. Observed heterozygosity within the new groups was between 0.51 and 0.60 . Hetero- 
zygosity within the group containing all Dahlem Reds individuals and one individual of the original group Jos was 0.56 (Table 4). Global significant test of deviation from Hardy Weinberg equilibrium revealed significant deviation for 4 of the new groups.

CHORD genetic distances observed between the new groups ranged from 0.09 to 0.27 and were substantially higher than between the original groups (Fig. 3). Genetic distances between the new groups and the group of Dahlem Reds and the one chicken from the original group Jos was between 0.2 and 0.34 , i.e. slightly lower than observed with the original grouping (Table 5).

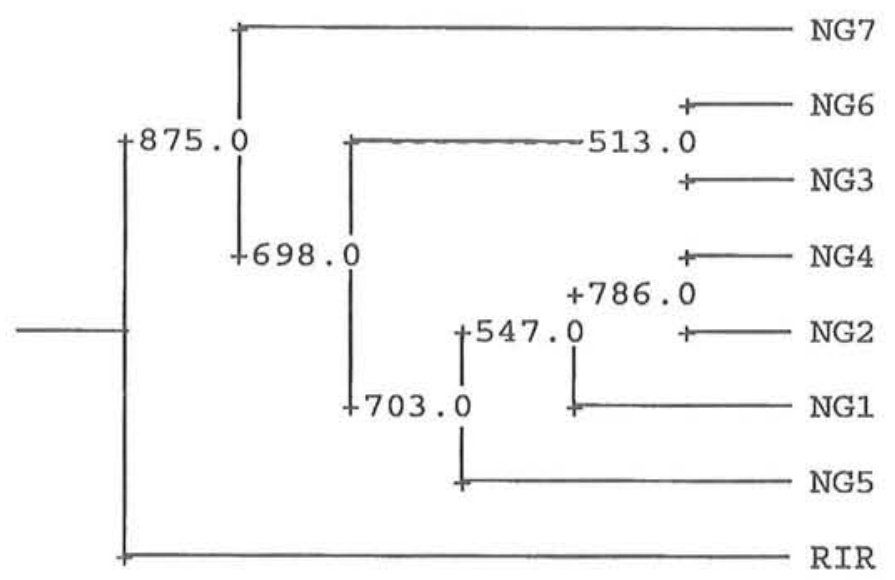

Fig. 3.: Dendrogram of 7 new groups of Nigerian chicken (grouped according to their genetic similarity) and RIR based on UPGMA clustering of CHORD genetic distance values (Dendrogramm der Nigerianischer Hühner in ihrer neuen Gruppierung (nach der genetischen Ähnlichkeit) und der Roten Rhodeländer basierend auf UPGMA-Klusteranalyse von CHORD genetischen Distanzen)

\section{Discussion}

Microsatellites are widely used to estimate genetic variation by the determination of heterozygosity and genetic distance, both from allele frequencies. BOWCOCK et al. (1994) showed that genetic trees of human individuals that were based on the calculation of allele sharing as a measure of genetic similarity reflect their geographical origin. We used the same approach to deal with the problem that individuals sampled in the same regions are obviously not representatives of distinct local populations. This problem often occurs in investigations of chicken populations sampled in different villages of developing countries due to the fact that they are not kept as close populations. The chicken used here were sampled in Nigeria and were originally assorted according to their geographical origin, but they showed substantial phenotypic variation.

Genetic variability estimates were based on a set of markers showing substantial heterogeneity in the number of alleles detected and polymorphic information content. The heterogeneity observed for the complete set of 20 microsatellites did not substantially exceed the heterogeneity observed for the microsatellites belonging to the set recommended by the FAO (Table 1). The use of a mixture of highly variable and less 
variable microsatellites should reduced the danger to overestimate genetic variability which might occur if only highly variable loci are used. Furthermore loci with more extreme diversity might on the whole be less informative due to presumably higher mutation rates (BOWCOCK et al., 1994).

For all groups of chicken high heterozygosity values were observed exceeding the values estimated for commercial breeds. Using 17 microsatellites in 15 commercial lines on average $42 \%$ heterozygosity were estimated with $53 \%$ for broiler lines and $27 \%$ for layer lines (CROOIJMANS et al., 1996). For the new groups we estimated similar heterozygosity values than for the original groups (Table 4). This indicates that heterozygosity is quite homogenous over all loci and over all individuals. Mean heterozygosity over all original groups was between $8.5 \%$ for locus ADL37 and 97.3\% for locus HUJ6, corresponding values calculated over all new groups were $12.4 \%$ for locus ADL37 and $96.7 \%$ for locus HUJ6. Differences between mean heterozygosity values estimated over all original or all new groups, respectively, were small.

In the global test for deviation from Hardy-Weinberg equilibrium significant deviation was found in all but 1 of the original groups. Deviations from expected values may be due to a variety of causes: inbreeding or outbreeding, selection, population size and structure, existence of "null alleles". If deviations from Hardy-Weinberg equilibrium are due to inbreeding or outbreeding, respectively, it should be present for many loci within the population and should be consistent in magnitude. Deviations due to selection are locus specific and should be consistent across populations. None of the ecotypes investigated showed only positive or negative deviations. Additionally for none of the loci investigated a systematic deviation across populations was observed. "Null alleles" have not been described for the microsatellites chosen and for none of the loci specific problems to obtain PCR-fragments at all occurred. In this study deviations from HardyWeinberg equilibrium are most likely caused by non-random sampling. Since excess and deficiency of heterozygotes at different loci within one population exist, it is, however, not expected that the heterozygosity estimates are biased. Though there was high phenotypic variation within the original local sample groups it is likely that related animals are within the original groups. After grouping the chicken according to their genetic similarity based on allele sharing significant deviation from Hardy-Weinberg equilibrium was found for four groups. It is remarkable that significant deviation from Hardy-Weinberg equilibrium was just found in the groups were a high proportion of individuals were grouped together which were also assorted to one of the original local sample groups, i.e. related individuals stayed together even after regrouping the animals. Of course, that is of disadvantage for the target to estimate genetic distances between local populations - a fact which results out of the shortcomings of the source of animals - but it supports the usefulness of the approach to sort individuals according to their genetic similarity by calculating allele sharing.

CHORD genetic distance between ecotypes was estimated based on 20 microsatellites taking into account recommendations from NEI and TAKEZAKI (1996) and the report of the FAO's working group of the "Integrated global programme to establish the genetic relationships among the breeds of each domestic animal species" (BARKER et al., 
1993).

Bootstrapping values obtained were between 46 and $99 \%$ indicating sufficient reliability of the results. For example BARKER et al. (1997) got bootstrapping values between 34 and $100 \%$ when analysing 11 Asian water buffalo populations with 25 individuals each with 21 microsatellites. In an study of evolutionary relationships between 6 sheep breeds (40 to 50 individuals each) BUCHANAN et al. (1994) reached bootstrapping values between $38 \%$ and $96 \%$ with 8 microsatellites.

CHORD genetic distance between the original Nigerian groups ranged from 0.05 to 0.15 and were substantially lower than the values observed for local populations from other countries (data not shown). Also genetic distance between Dahlem Reds and the original groups of Nigerian chicken were lower than observed for other exotic local populations, i.e. the Nigerian populations were much more close related to the Dahlem Reds than the other exotic populations with the group of Kaduna showing the highest distance to the Dahlems. The close genetic relationship of the Nigerian groups to Dahlems may be due to the efforts made during this century to improve the local chicken populations by crossing with exotic commercial chicken. Even the close genetic similarity between the populations from Nigeria when compared with the relationships among the other populations from different countries might be caused by the crossing with commercial exotic breeds. But the genetic distance to the commercial breed was still sufficient to expect high heterosis from a cross.

Genetic distance between the groups of Nigerian chicken was low. The chicken also showed great phenotypic variation between and within the ecotypes. The low genetic distance among Nigerian ecotypes support the suggestion that these do not represent well defined genetic groups which share particular characteristics. The main goal of the project was to identify local chicken populations which are worth being regarded as genetic resources and therefore should be preserved or utilised in breeding programs for genetic improvement of poultry production. To approach this chicken were arranged in new groups which were most distant to each other and commercial chicken. This was done by (1) calculation of allele sharing, AS, between the individuals, (2) use of 1-AS as a distance measure and (3) construction of a dendrogram by UPGMA analysis and (4) subsequent analysis of genetic distance between the new groups. For this process of regrouping one has to find a compromise: on one hand the new groups should be as large as possible in order to allow a reliable genetic distance estimation, but on the other hand the new group should consist of animals which are genetically more similar than the original groups. A reference to perform the regrouping is given by the genetic distance between the Dahlem Reds, i.e. the branch length of the subcluster including the Dahlem Reds. Consequently this was used coming up to 7 new groups. When a lower number of larger groups (4) was chosen the genetic distances between these groups indicated that they were less distinct than the original group. CHORD genetic distance between the new groups was significant higher than between the original groups with values between 0.07 and 0.27 . Genetic distance between the new groups and the new group consisting of all Dahlem Reds was lower than the between the original groups. This might be due to the fact, 
that the new group of Dahlem Reds contained one exotic chicken. Unfortunately the new groups were also quite small as the original groups. But they were more distinct. Since heterosis tends to increase with genetic distance of parental populations, for breeding programs aiming at the use of heterosis by crossbreeding one could close up with the recommendation to design an appropriate breeding program using the new grouping of the chicken rather the original one.

In conclusion, the suitability of the approach to group individuals according to their genetic similarity by calculating allele sharing based on microsatellite analysis is demonstrated here by the fact that the individuals of Dahlem Reds - which represent a well defined population the members of which share particular morphological and/or genotypic characteristics - cluster within the tree. The regrouping done here is reasonable since an acceptable compromise was found between the aim to build up groups which are more distinct than the original ones and the aim to come up with new groups being as large as possible in the given material. The genetic distances between the new groups increased when compared with the distances between the original groups. The calculation of allele sharing as a measure of genetic similarity is a suitable approach to assort individuals to new groups according to their genetic similarity in order to support the selection of individuals for maintenance as genetic resources and
for crossbreeding.

\section{References}

BARKER, J.S.F.; BRADLEY, D.G.; FRIES, R.; HILL, W.G.; NEI, M.; WAYNE, R.K.

An Integrated Global Programme to Establish the Genetic Relationships among the Breeds of Each Domestic Animal Species. - Report of a Working Group, Animal Production and Health Division (1993),
FAO

BARKER, J.S.F.; MOORE, S.S.; HETZEL, D.J.S.; EVANS, D.; TAN, S.G.; BYRNE, K.:

Genetic diversity of Asian water buffalo (Bubalus bubalus): microsatellite variation and a comparison with protein-coding loci. Animal Genetics 28 (1997), 103-115

BOTSTEIN, D.; WHITE, R.L.; SKOLNICK, M.; DAVIS, R.W.:

Construction of a genetic linkage map in man using restriction fragment length polymorphisms. American Journal of Human Genetics 32 (1980), 314-331 BOWCOCK, A.M.; RUIZ-LINARES, A.; TOMFOHRDE, J.; MINCH, E.; KIDD, J.R.; CAVALLI-SFORZA,
L.L.:

High resolution of human evolutionary trees with polymorphic microsatellites. Nature, London 368
(1994), 455-457

BUCHANAN, F.C.; ADAM, L.J.; LITTLEJOHN, R.P.; MADDOX, J.F.; CRAWFORD, A.M.: Determination of evolutionary relationships among sheep breeds using microsatellites. Genomics 22
(1994), 397-403

CAVALLI-SFORZA, L.L.; EDWARDS, A.W.F.

Phylogenetic analysis: models and estimation procedures. Evolution 32 (1967), 550-570

CROOIJMANS, R.P.; GROEN, A.F.; VAN-KAMPEN, A.J.; VAN-DER-BEEK, S.; VAN-DER-POEL, J.J.;
GROENEN, M.A.:

Microsatellite polymorphism in commercial broiler and layer lines estimated using pooled blood FRANKHAM, R.:

Conservation of genetic diversity for animal improvement. In: Proceedings of the $5^{\text {th }}$ WCGALP 21 (1994), 385-392 
Arch. Tierz., Dummerstorf 42 (1999) 6, 640

\section{Mitteilung der Redaktion}

Aus technischen Gründen erscheint das Inhaltsverzeichnis des Bandes 42 (1999) dieser Zeitschrift im Heft 1, Band 43 (2000).

\section{Communication of the editoral office}

For technical reasons the table of contents of the year 1999 volume 42 appears to this journal in the issue one volume 43 / 2000. 
Arch. Tierz. 42 (1999) 6

NEI, M.; TAKEZAKI, N.:

Reconstruction of phylogenetic trees from microsatellite (STR) loci. In: Proceedings. of the XXVth International Conference on Animal Genetics, (1996), 2-5

RAYMOND, M.; ROUSSET, F.; SLATKIN, M.:

Genepop (V1.2): A population genetics software for exact tests and ecumenicism. The Journal of ROHLF, F.J.: Heredity 86 (1995), 248-249

NTSYS-pc numerical taxonomy and multivariate analysis system. V.s. 1.80. (1993) Exeter Publishing LTD, Setauket, New York

Received: 01.04.1999

Accepted: 03.08.1999

Authors'addresses

Dr. KLAUS WIMMERS, Dr. SIRILUCK PONSUKSILI, Dr. FRIEDRICH SCHMOLL, Prof. Dr. KARL SCHELLANDER

Institut für Tierzuchtwissenschaft

Landwirtschaftliche Fakultät der Rheinischen Friedrich-Wilhelms Universität Bonn

Endenicher Allee 15

D-53115 Bonn

Germany

E-Mail: wimmers@itz.uni-bonn.de

Dr. TORSTEN HARDGE, Prof. Dr. PETER HORST

Institut für Nutztierwissenschaften

Landwirtschaftlich-Gärtnerische Fakultät der Humboldt-Universität zu Berlin

Invalidenstr. 42

D-10115 Berlin

Germany

Prof. Dr. E. BABAFUNSO SONAIYA

Department of Animal Science

Obafemi Awolowo University

Ile-Ife, Nigeria 